\title{
右脚ブロックの体表面心臟電位図 （特に心房中隔欠損症を中心として）
}

一超音波検查, 右心カテーテル検査との对比一

岡山大学医学部第一内科教室（主任：長島秀夫教授）

吉田英紀 - 庵谷和夫 - 長花晴樹

西原正信 - 兵頭多津男 - 内田俊明

木村正司 - 武田光 - 藤井章伸

斉藤大治

㮔原十全病院

種谷節郎・喜多利正 - 堺裕

岡山大学医学部附属病院中央検査部

原岡昭 -

(昭和 56 年 4 月 18 日受稿)

Key words：体表面心臓電位図，右脚ブロック， 心房中隔欠損, Breakthrough

\section{緒}

\section{言}

右脚プロックの心電図についての実験的, 臨 床的な報告は多いが市３，従来の標準12誘導心 電困やへクトル心電図では誘導点が少なく，右 脚ブロックで生じた体表面上での全ての電位変 化を解析するには不充分である.体表面心蔵電位 困(以下電位図)は，従来の心電図では誘導しな い，右前胸部や背部などの多数の誘導点からも 心電図を記録するので，右室の電気現象に関し て非常に多くの情報をうることができると考え られ，右脚ブロックの診断手段として，よりす ぐれた方法であると考えられる4．特に，右脚 ブロックでは，興鹪の心外膜面への到達を示す と考えられている Breakthroughが, 右室伝導 遅延に伴い, その出現時間が遅延し, その位置 も左方に偏位する点が注目されている4). そこ で著者らは，心電図で右脚プロックを呈する，
心房中隔 2 次孔欠損症 (以下ASD)，心内膜床欠 損症（以下 ECD），心血管系に異常を認めない 右脚ブロックを対象に，中日電子社製HPM5100 の体表面心臓電位図作成装置を用い，名大環研 の山田らの方法に従い5)，体表面87点より， Wilson の中心電極を 0 電位とした単極誘導心 電図を記録し，電位図を作成，検討し，更に超 音波㭘査, 右心カテーテル検查成績とも対比, 検討した。

\section{対象と方法}

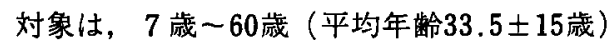
の ASD (男14例，女16例）の30例， 7 歳 16 歳のECD (女 3 例) で, 对照として心電図上で 右脚ブロックを呈するが心血管系に異常を認め ない 5 例（男 4 例，女 1 例)，平均年粭 $32.0 \pm$ 16歳をえらんだ。標準12誘導心電図の所見は, ASDのうち 2 例が $V_{1}$ 誘導で $\mathrm{rS}$ notchを認め 
た他は，ASD，ECD例とも完全または不完全右 脚ブロックと右室肥大の所見を示していた。ま た ECD 例は, 3 例とも $-60^{\circ}$ 以上の左軸偏位を 伴っていた，以上のほかに，正常心電図を示す 6 例についても電位図を記録した。電位図は， 中日電子社製 HPM-5100を使用し, 名大環研の 山田らの方法 ${ }^{5} に$ 従い，体表面87点からWilson の中心電極を 0 電位とした単極誘導心電図を記 録して作成した。尚, ASD 25例, ECD 3 例に ついては右心カテーテル検查を施行し，AＳD 29例，ECD 3 例は，東芝株式会社製 SSH-11 A 心臟超音波断属装置を用いて検查を施行した。 そして，電位図から得られた，Breakthrough minimumの出現時間及び出現部位, QRS 後期 の電位図の型や右前胸部におけるQRS の最大 電位など，右室負荷による右室伝導遅延ないし 右室の肥大などが関係していると考えられる諸 指標を, 右室負荷の心血行動態的指標として心 臓カテーテル検查より得られた, 平均右室圧, 平均肺動脈圧, 肺体血流比( Qp /Qs), 左右短絡率 などの值と, また右室拡張の指標として心臓超 音波検查上り得られた, 右室拡張期径, 右室拡 張期径/左室搪張期径などの值と対比し，それ らの間の相関関係の有無について検討した.

\section{結果および考案}

正常心電図を示才23歳，男子の電位図を図 1 に示す，名大環研の山田らの正常電位图とほぼ 同様の型を示した6).すなわち QRS 開始後 10 msec では，興舊前面は心室中隔を左室側から 右室側へ向かい，主に前方に進んでいる。この 為,興奮前面を迎える側である前胸部で正に(図 1 の電位図の左半分), 見送る側である背部は負 領域で覆れる.(図1の電位図の右半分) $19 \mathrm{msec}$ では興䍃前面は左室心内膜下を心外膜方向へ, 右室心内膜下を前方へ進んでおり，この時の電 位図は $10 \mathrm{msec}$ 時と同じ型を呈しているが，前 胸部の電位がやや高くなっている。 $21 \mathrm{msec} に$ なると左室を左方に向かう優勢な興䬺前面を反 映して左胸部に正領域および極大（十）が, 右 胸部に負領域が存在し, 特に興隹の右室心外膜 面への到達を示すと考えられる breakthrough を反映しで）前胸部中央に極小（一）が出現し，
Control

Normal. 23y. M.

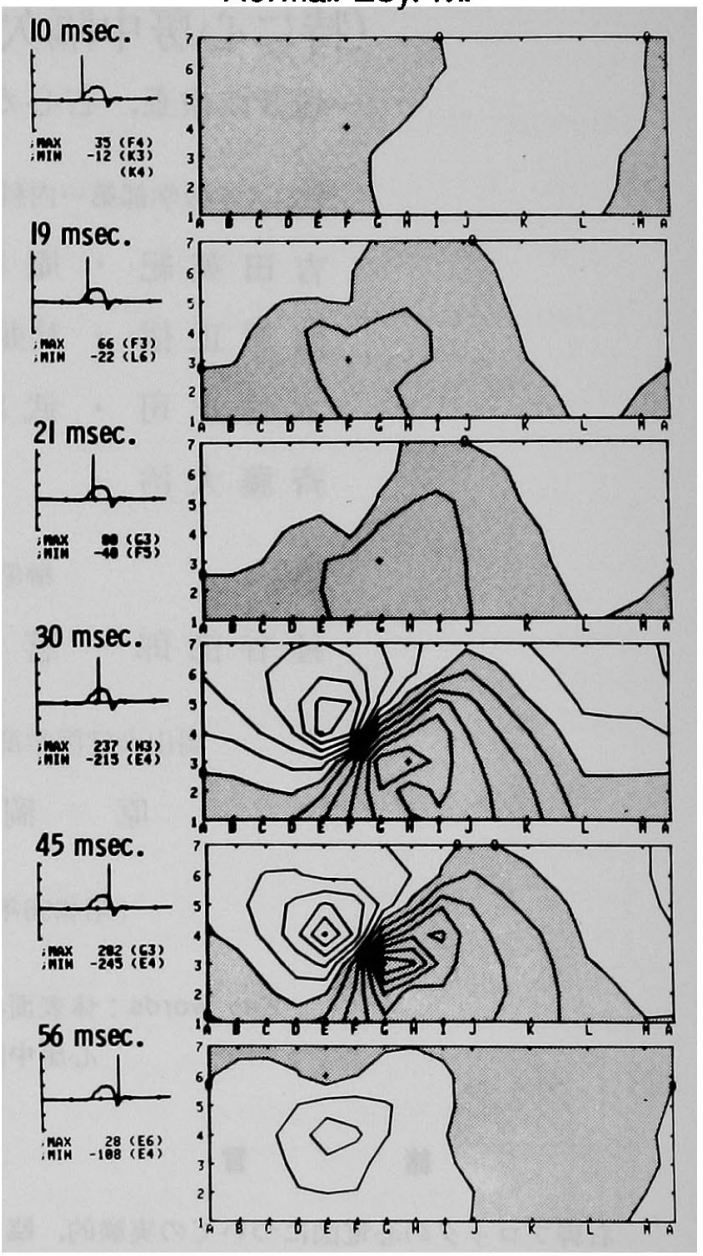

図 1．23葴の健常男子の電位図

左側にQRS 開始からの時間 (msec) とG-4 誘導点でのQRS 波を示す。困の灰色の部分は 正電位領域を示し，そのうちで最大の電位を極 大 $(+)$ で示す。白色の部分は負電位領域を示し, そのうちで最小の電位を極小(ー)で示す。等電 位間隔は， $0.4 \mathrm{mV}$ で示す.

この極小による正領域の陥凹 (niche)がみられ る。この右室の breakthrough を反映する極小

(Breakthrough minimum) などの所見は従来 の標準12誘導心電図やべクトル心電龱では得難 い情報である，Taccardi ら7)，菅屋8) は，右脚 ブロックでは，右室興僵の心外膜面への到達を 表わす breakthrough minimum の出現が正常 
に比して著しく遅れ，その部位も左鎖骨中線寄 りに偏位するとし，その理由を右室伝導遲延に より，興奮が右室心外膜へ破れ出たことに帰し， 右脚ブロックの特徴とした。そして，右脚ブロ ックの程度が高度である程, breakthrough minimum の出現時間も遅延し，出現部位もより 左方に偏位するとしている。 $30 \mathrm{msec}$ から 45 msec では興奮前面は主に左室を左後方へ進む ため，電位図では正領域および極大は左胸部か ら背部へと移動し，負領域および極小は右胸部

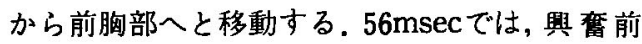
面は肺動脈円錐部と左室側後壁に存在するため, 電位図では前胸部上方と背部が正領域で覆われ る. 以上が正常電位図の型である。

次にASD例の実例を示す。

33葴の男性, 心電図(図2)は $V_{1}$ 誘導で $Q R S$

\section{H.H.37y M. ASD}

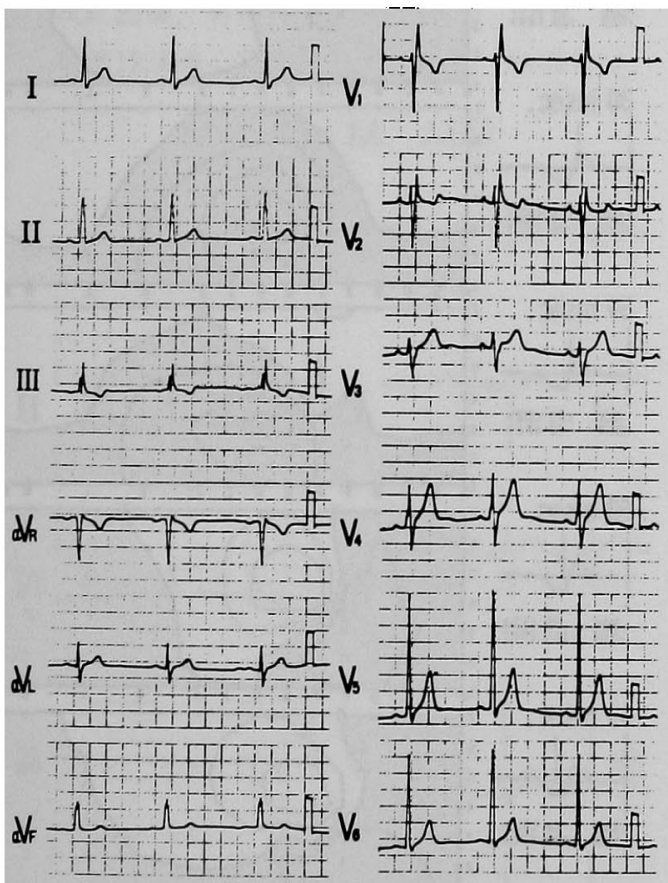

図 2、37蔵の男性の ASD 症例の標準12誘遵心電困

棘波は $\mathrm{rSR}^{\prime}$ 型で $\mathrm{QRS}$ 間隔は 0.12 秒で完全右脚 フロックを示し， $\mathrm{R}^{\prime}$ 波高は $1.1 \mathrm{mV}$ と高電位で あり，また $\mathrm{V}_{5}, \mathrm{~V}_{6}$ 誘導での $\mathrm{R}$ 波高の増大を認 めた. 右心カテーテル検查では, 平均右室圧 (以 下 $\mathrm{mRV}$ pressure） $5.5 \mathrm{mmHg}$ ，平均肺動脈圧
(以下 mPA pressure) $8 \mathrm{mmHg}$ ，肺体血流比 (以下 Qp/Qs) 2.2，左右短絡率（以下S.R.) $47 \%$ で，手術時に径 $1.5 \mathrm{~cm}$ の欠損孔を確認して いる。它臓超音波検査で，右室拡張期径（以下 RVDd） $28 \mathrm{~mm}$ ，右室拡張期径／左 室 拡張期, 径 0.62 であった。臨床症状は NYHA 分類のII 度 であった。電位図は（図 3 )，心室興奮の始め

Group I

H. H. 37y. M. ASD

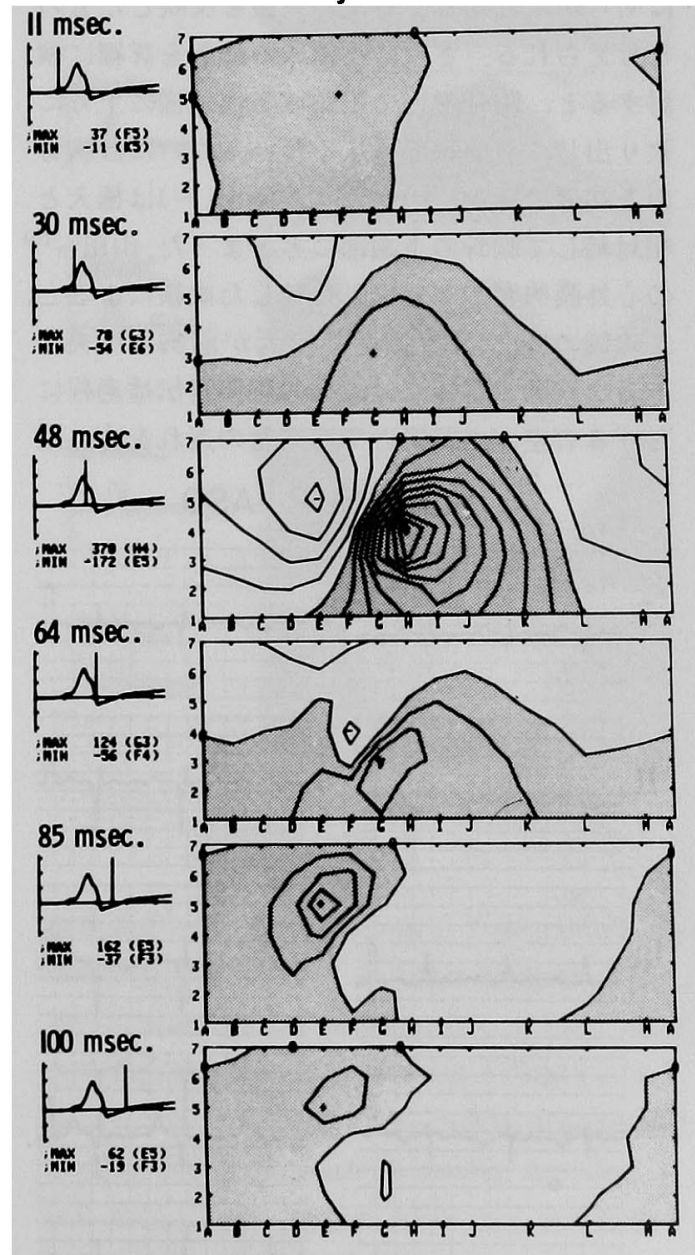

図 3．37葴の男性の ASD 症例の電位図 (説明は本文中)

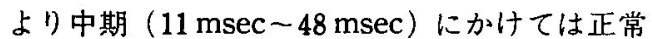
例とよく似た型を示したが，64 msec とQRS開 始よりかなり遲れた時点で，F-4 と，胸骨より 左方に偏って Breakthrough minimum が出現 
し，この極小を頭に，その周辺の零電位線が正 電位領域内人揳形に食い込んで(いかゆるniche) 右脚ブロックに特徴的な所見を示しており，右 室前面の興奮伝導の遅延の程度が大きいことを 示唆している.その後, QRSの後期（85 msec ～100msec）では，正常電位図と異なり，右前 胸部と右背部は常に正領域であった。菅屋らの 犬での右脚本幹切断時の電位図 ${ }^{9)}$ も同様のパ夕 一ンを示しており，このことから，この正領域 は明らかに䐅延した右室の興鹪を反映したもの と考えられる。ささに正領域の動きを詳細に検 討寸ると，胸骨附近で正領域が偽足様に上方に 張り出し，右前胸部を広く覆い，ついには胸骨 の上端部に極大 $(+) か ゙$ 生じ, 極小 $($ - )は極大と 相对峙して胸骨の下端部にとどまった。山田ら(10) の心外膜興奮伝播過程と比較した成績によると， この例の様にQRS 後期に極大が前胸部中央を 上方に移動する例では，心外膜興圊伝播過程に おける右室流出路附近での興奮の遅れをよく反

\section{K. A. 16y F. ASD}

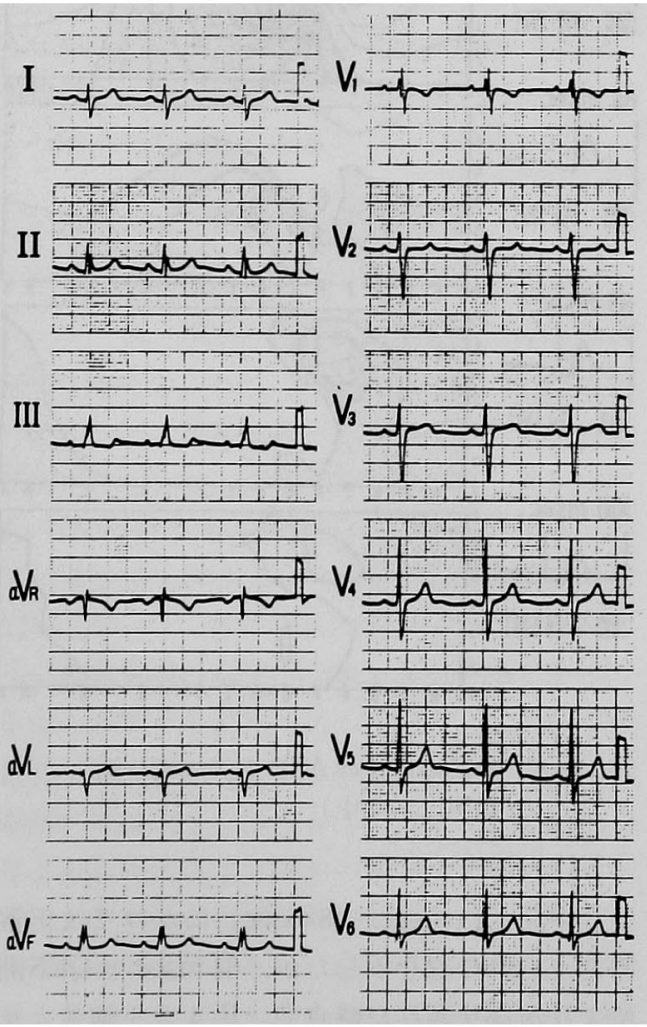

図 4.16歳の女性の ASD 症例の標準12誘導心電図
映したものと考えられ，ASD，ECD例でQRS 後期の極大の位置が胸骨上方にある型を示すも のを，山田ら ${ }^{10)}$ の分類に従いGroup I とした． 次に16歳，女性の ASD例を示す。

心電図では（図 4 ）， $V_{1}$ 唀導で, QRS棘波は rsr's'型を示す不完全右脚ブロックである. 右心 カテーテル検查では, $\mathrm{mRV}$ pressure $13 \mathrm{mmHg}$, mPApressure $16 \mathrm{mmHg}, \mathrm{Qp} / \mathrm{Qs} 1.7$, S.R. 39 $\%$ ，心臓超音波検查では RVDd 25mm, RVDd/ LVDd 0.68であった。臨床症状は，NYHA 分 類のI度であり，第 1 例目より軽症であった。 電位図では，図 5 に示す如く，QRS 開始から

\section{Group II}

K. A. 16y. F. ASD

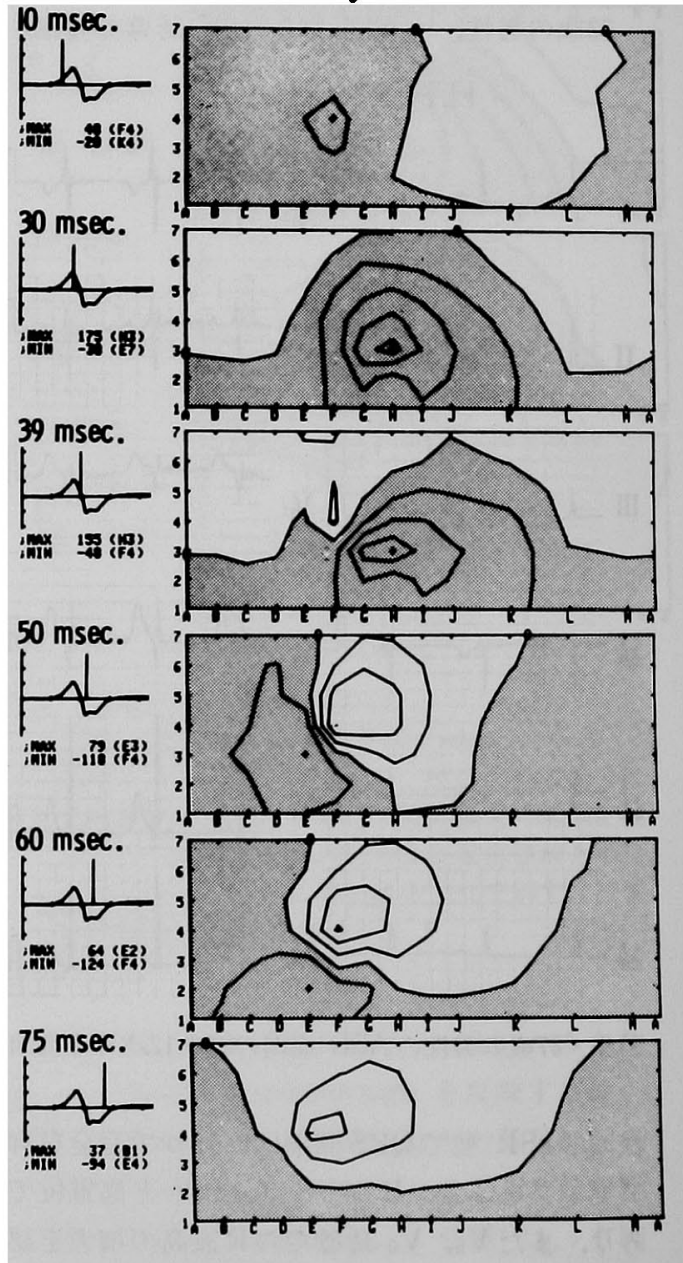

図 5.16歳の女性の ASD 症例の電位図 (説明は本文中) 


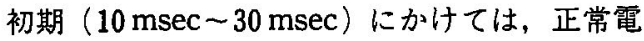
位図とよく似た型を示すが，39 msec と正常よ り少し遅れた時期にF-4 と胸骨の左方に偏って Breakththrough minimum が出現した。その後, この極小を先頭に負領域が正領域に楔状に入り 込み，左前胸部の正領域を左下方へと圧迫して いった. QRS 開始後60msec $\sim 75 \mathrm{msec} の$ 終期に は，極小は下方へ移動し，極大および正領域は 右下方へと移動した。この型をとるものは, Fallot の症例に多〈認妨々れるいわれており1! ASDによる右室搪張負荷に右室肥大を伴って 来たものと考えられ，山田らの心外膜興奮伝幡 過程と比較した成績10)でも，右室流入路附近で の興奮の遅延を反映していると考えられている。そ の例の様にQRS 後期に極大が前胸部中央を右 下方に移動するものを，山田ら ${ }^{10)} の$ 分類に従い Group II とした。

次に25歳，男性の ASD 例を示す。

標準12誘遒心電困のみでは, $V_{1}$ 誘導では,

\section{Y. 25y. M. ASD}

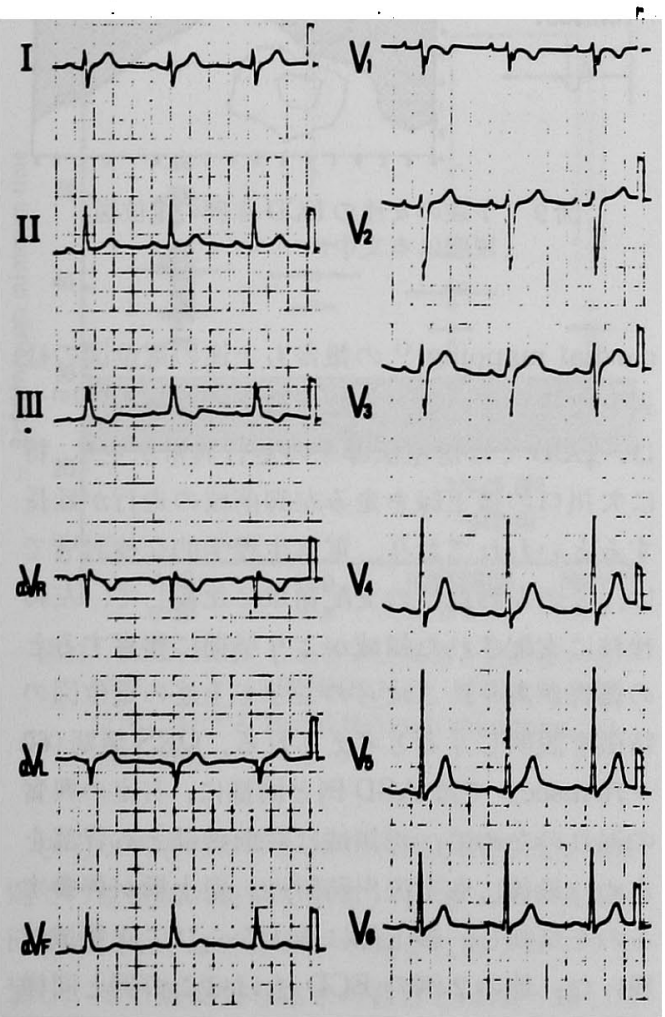

図 6．25歳の男性の ASD 症例の標染12誘導心電図
rS notchのみであった（図6）電位図でみる と，図 7 の如く，34 msecと正常より約10 msec

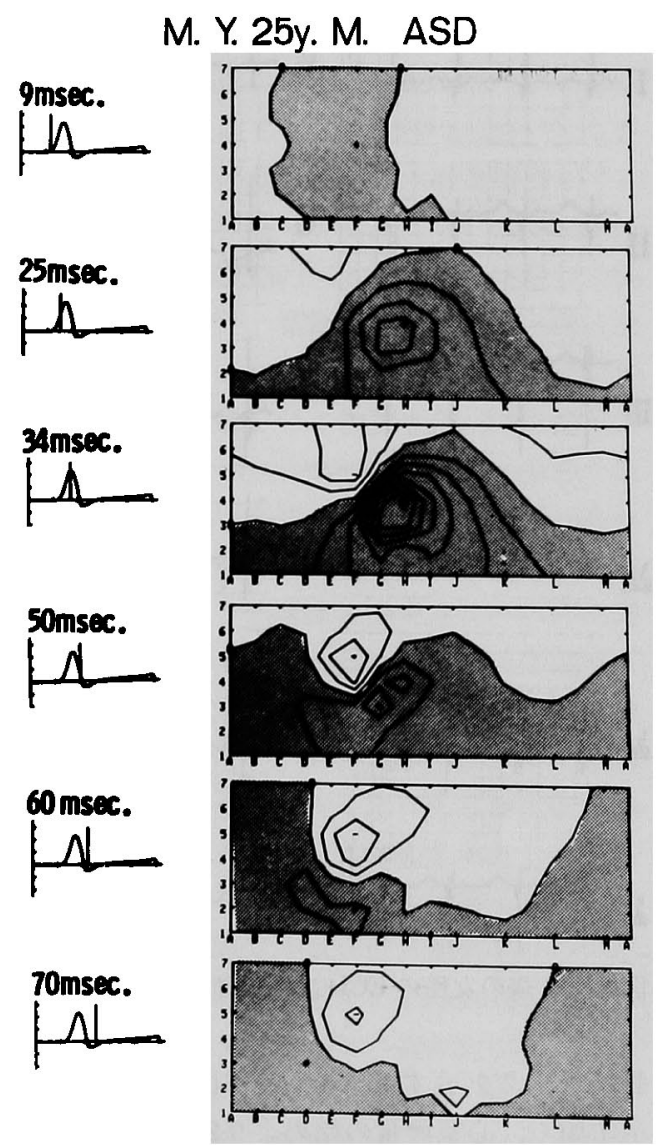

図 7.25歳の男性の ASD 症例の電位図 （説明は本文中）

前後遅れて,F. 5 と左方へ偏って breakthrough minimum が出現し，その後は GroupIIの様に， 右下方へ極大および正領域が押しやられ，右室 の興奮伝導䐅延があることが良く理解される. 右心カテーテル検查では, mRV pressure 10 $\mathrm{mmHg}, \mathrm{mPA}$ pressure $16 \mathrm{mmHg}, \mathrm{Qp} / \mathrm{Qs} 1.4$, S.R. 30\%と比較的軽症の ASD の心血行動態を

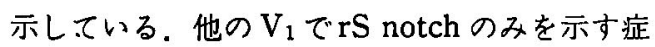
例でも，この例同様，電位図を記録すれば，明 らかに右室の興奮伝播遅延を把握することが可 能である.心内膜床欠損症 (E.C. D.)に於いて は，多少 ASD 二次孔欠椇症とその電位図パ夕 ーンを異にしている。

症例は 7 葴の女性で, 心電図は $-60^{\circ}$ 以上の 著明な左軸偏位と, $V_{1}$ 誘導で $r s R^{\prime}$ の不完全右 
M. H. 7y. F. EDC

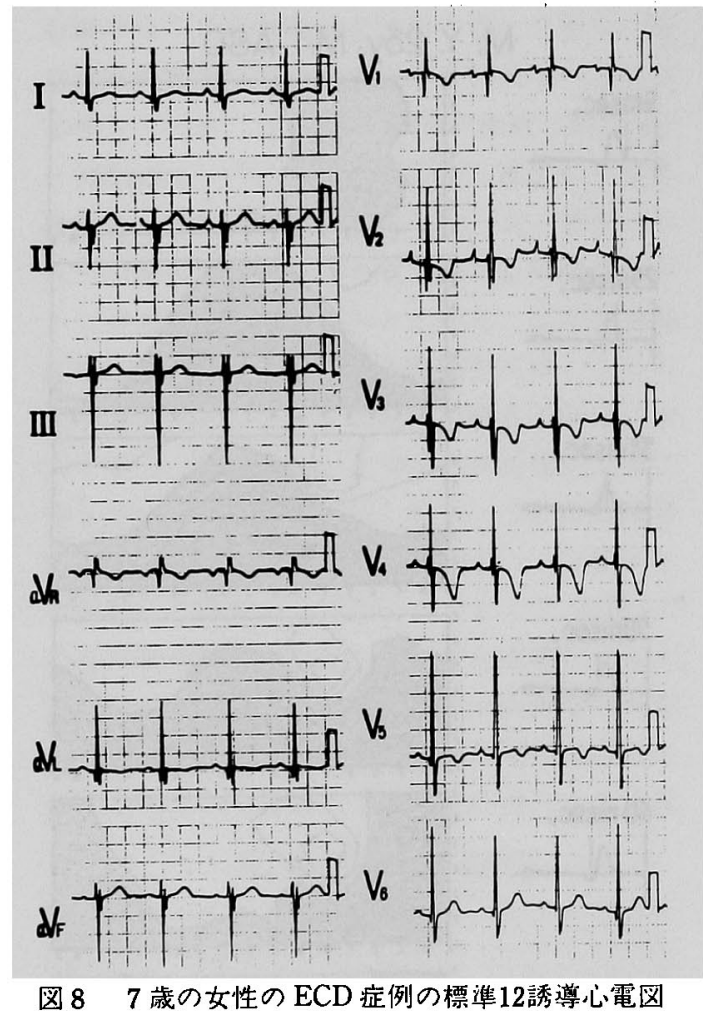

脚ブロックを示す. (図 8 ) 電位図では, 図 9 に 示す如く，心室興奮の始めより $23 \mathrm{msec}$ での電 位図は，正常例や ASD 例と異なり，負領域が前 胸部と背部を覆った。これは心室興奮が正常興 窗過程を進まずに，後方から前方，すなわち左 室後底面から主として前上方に進行することを 反映していると考えられる． $41 \mathrm{msec}$ 後にはI2 と左下方に偏って新しい極小, Breakthrough minimum が出現し, ASDのそれと比 へて正領域と負領域の分布が逆になり，右前胸 部の下半分と背部の下半分が負領域に覆われる。 正常電位図（図1) の同時期 (45 msec)のそれ では，正領域は背部全体を覆ったが, ECDの例 では，正領域は背部上 $1 / 2$ を負領域が背部下 $1 / 2$ を占めている。これは正常の興巂伝播過程では 心室興奮の後半に興奮する左室後底面の部分が ECD では既に興奮を終了しているためと考える ことができ, ECDの患者の開腘術時の epicardial mapping 13141)15) やECD のある犬心臟の epi-

\section{H. 7y. F. ECD}

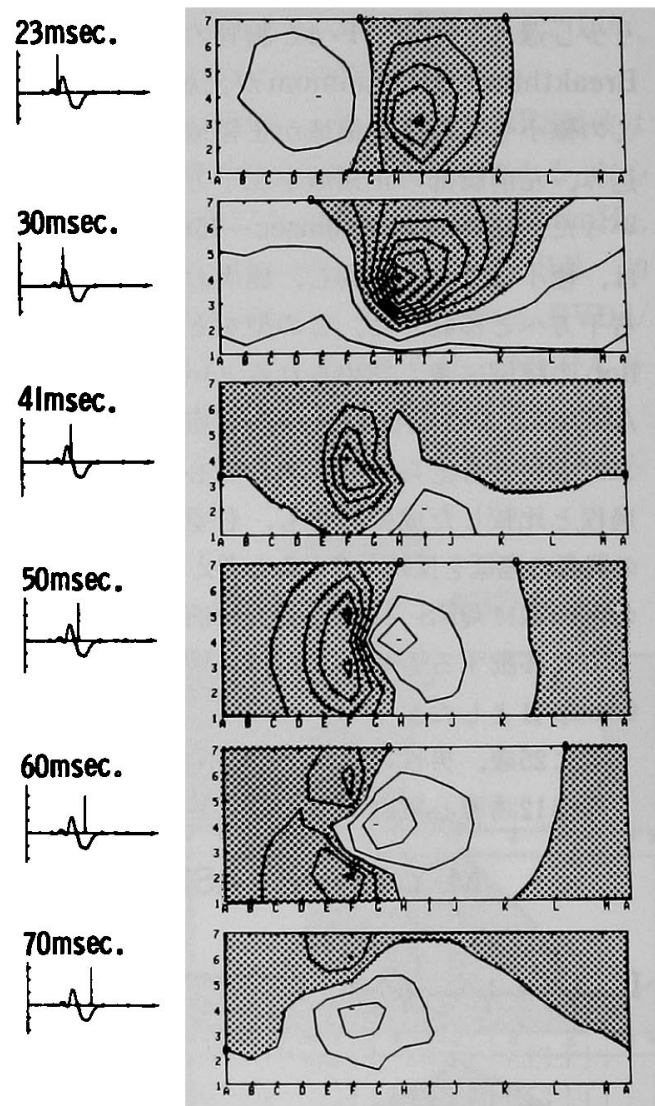

困 97 葴の女性の $\mathrm{ECD}$ 症例の電位図 （説明は本文中）

cardial mapping ${ }^{14)}$ の報告も上述の電位図の経 過を支持している。また組織学的な検査 ${ }^{14) 16) て ゙ ~}$ は, ECD では房室伝導系の走行異常が生じ, 特 に欠損口の後下縁を走る左脚前忮の走行が延長 するといわれており, 電気生理学的な検討 ${ }^{13)}$ は，この左脚前忮の支配領域に比较して, 左脚 後忮に支配された領域がより早期に興奮すると の報告があり，これらのことも上述の電位図の 特徵を説明しうると考之られる。 QRS 後期 $(60$ $\sim 70 \mathrm{msec}$ ) では ASD 例と同樣に, 右室の興奮 の遲れのために，正領域は右前胸部と右背部を 占め, 最後に右室流出路附近, 室上楖が興翼す るのを反映し、胸上部に極大ならびに正領域が 残った。他の 2 例の ECD もほぼこの例と同様 のパターンを示し, 山田らの報告 ${ }^{12)}$ と一致した。 


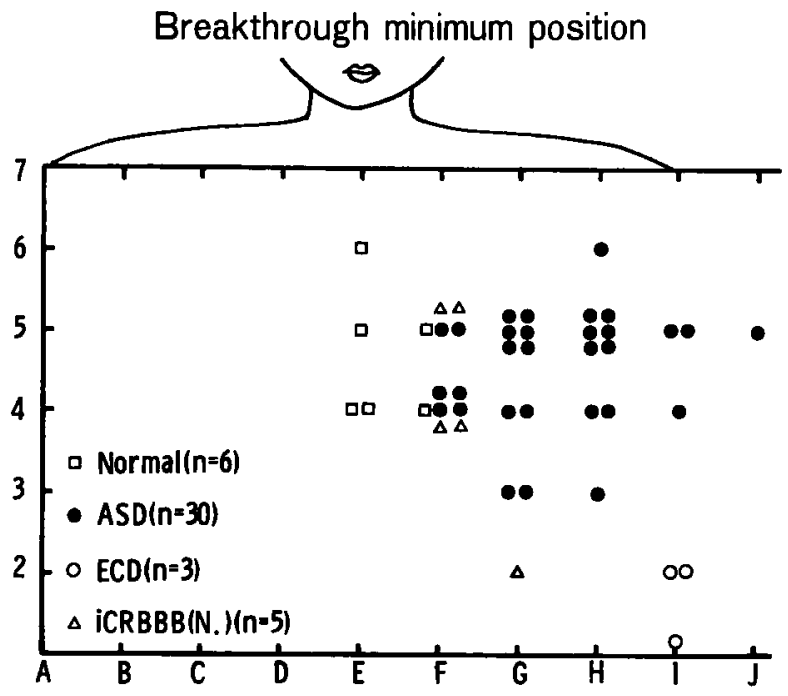

図10 ASD, ECD, 心血管系に異常を認めない右脚 ブロック (iCRBBB(N.)]，健常者例の電位図に おける Breakthrough minimum $の$ 出現部位

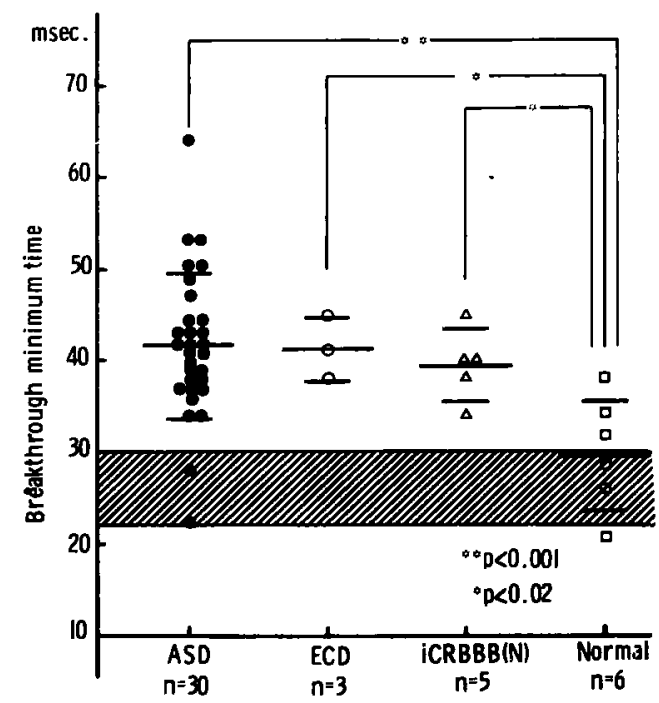

図11 ASD, ECD, 心血管系に異常を認めない右 脚ブック〔iCRBBB(N.)〕, 健常者例の電 位图における Breakthrough minimum の 出現時間

以上が著者らが手がけた ASD, ECD及び正常 例での電位図の実例である。著者らの ASD, $\mathrm{ECD}$ 例では，ほとんどが不完全右脚ブロックを 呈し，その電位図も諸家の報告とほぼ一致した 4)78)11112)。一般に不完全右脚ブロックの成因と
しては，1)右脚の moderator bandの 傷害によるとする説 ${ }^{18)}$ ．2)右室流出路 の肥大による部分的な伝導障害 ${ }^{7}$. 3)右 室の拡張による右室肥大 ${ }^{111414}$.などが 考之られている. ASDにおいて、これ らのどの成因が、どの程度関与してい るかは不明である。犬の moderator bandに相当する右脚側枝を切断した実

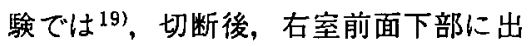
現していた breakthrough が左室心尖 部に出現したと報告され, ASD 症例に おける breakthrough は右室前面に出 現している(10)点からも moderator band の障害説は, ASDの不完全右脚 ブロックの成因とは考之にくいとの報 告もある10). ASD に合併する不完全右 脚ブロックの成因を電位図の型から推測 すると，山田らの I 群(著者らの Group I) では，右室流量負荷に伴う右室内腔の拡張 により右脚伝導系の延長や伸展を来たし, 左脚 系に比し右脚伝導系の伝導が相対的に遅延し, 特に右室流出路附近で遅れると解釈される ${ }^{14) 20 \text { ) }}$ また山田らのII群（著者らの Group II）は，右 室流量負荷に併う右室基部の選択的な肥大によ リ，右室流入路の伝尊遅延を来たしたものとし て解釈される181211. 著者らは、これら ASD, $\mathrm{ECD}$ 症例での電位図のタイプの違いが, ASD, $\mathrm{ECD}$ の病態の差, 病期の差, 合併症などと関係 があるのかどうかを検討する目的で，心臓力テ 一テル検查での右心系の血行動態的指標および 心臟超音波検査からの右室拡張の諸指標と対比 検討を試みた。まず Breakthrough minimum の出現部位は (図10),正常例（口印），心血管系 に異常を認めない不完全右脚ブロックでは，1 例を除いて大部分が $E, F$ 周辺の胸骨正中ない し左縁に出現したが，ASD 例（○印）では，6 例はFに出現したが他の26例は全て，それより さらに左方に偏って出現した.ECD 例（O印） では， 3 例とも II - 1，I - 2 と左下方に偏位 して出現するのが特徵的であった.Breakthrough minimum の出現時間を四11に示す.斜線の範囲 は、山田らの健常者26例での正常範囲（平均26 $\pm 4 \mathrm{msec}, \mathrm{n}=26$ ）であるが5)22），著者らの正常 

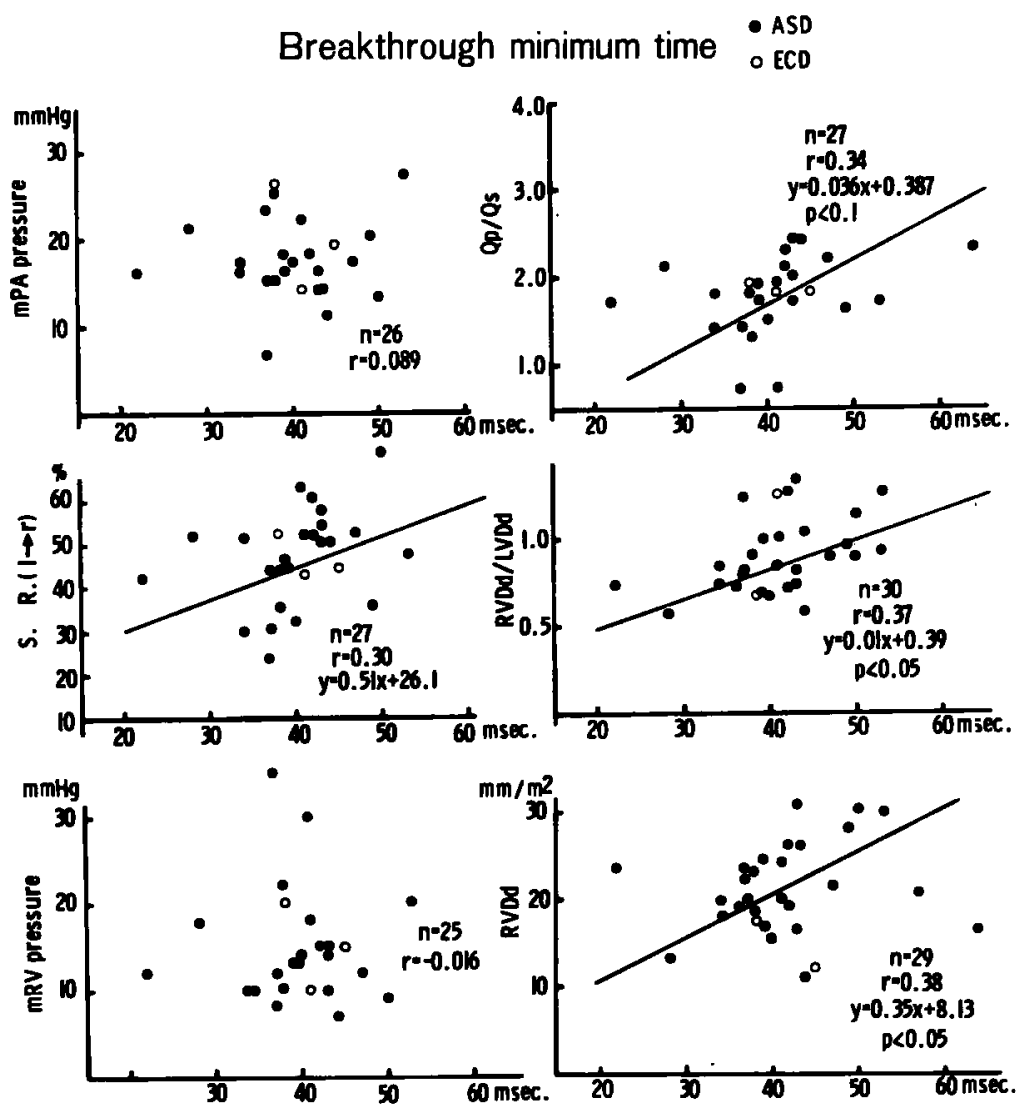

図12 ASD, ECD 㱏例の電位図における Breakthrough minimum の出現 時間と, 平均肺動脈压 (mPA pressure), 平均右室圧( $\mathrm{mRV}$ pressure), 左右短絡率 [S.R. $(\ell \rightarrow \mathrm{r})]$, 肺体血流比 (Qp/Qs), 右室拡張期径/左室拡張期 径 (RVDd / LVDd)，体表面穔で補正した右室拡張期径 (RVDd) との 对比

6 例では (平均29.5土6.0 msec) 少し遅れてい るが, 大体はよく似た時間带に出現している. しかし ASD 例 $(41.6 \pm 7.9 \mathrm{msec}), \operatorname{ECD}(41.3$ $\pm 3.5 \mathrm{msec}$, 心血管系に異常を認めない不完全 右脚ブロック例 $(39.4 \pm 4,0 \mathrm{msec})$ ともに10 $20 \mathrm{msec}$ 程度の出現時間の遅れがみられたが, 各群間では差は認めなかった。すなわち Breakthrough minimum は, ASD, ECD 例では，心 血管系に異常を認めないものより，有意に遅れ て，より左方に偏って出現するといえる，そこ で ASD， ECD 例の電位図での Breakthrough minimum の出現時間と, mPA pressure, mRV pressure, Qp / Qs, S.R., RVDd（体表面積で補 正した右室拡張期径)，RVDd/LVDd，との関
係につき検討した.(図12) mPA pressure, m RV pressure との相関は得られず，わずかに S.R. (左右短絡率)，Qp/Qs (肺体血流比) が大 になるにつれ, Breakthrough minimum の出 現時間も遅れる傾向を示し, RVDd, RVDd/ LVDdが大きくなるにつれ，すなわち右室拡張 の程度が大になるにつれ，5\%以下の危険率で 有意に Breakthrough minimum の出現時間は 迤延することが認められた。今回の症例の中に は, mPA pressureや $\mathrm{mRV}$ pressure が著堌を 示す重症例が少なく，大部分が正常ないしは軽 度の右室圧, 肺動脈圧の増加を示すものであり， よい相関が得られなかったものと考えられ，重 症度の指標として，S.R.や Qp /Qs，右室径など 
Breakthrough minimum position
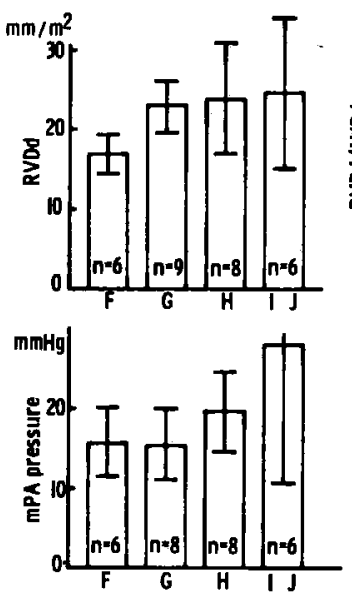
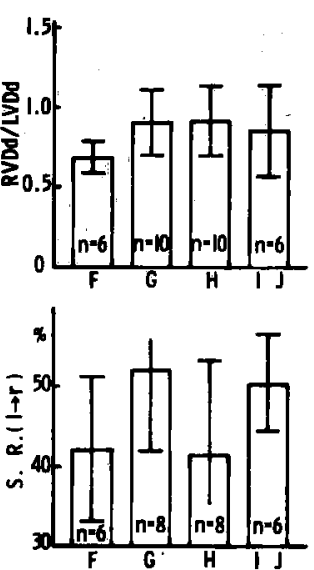
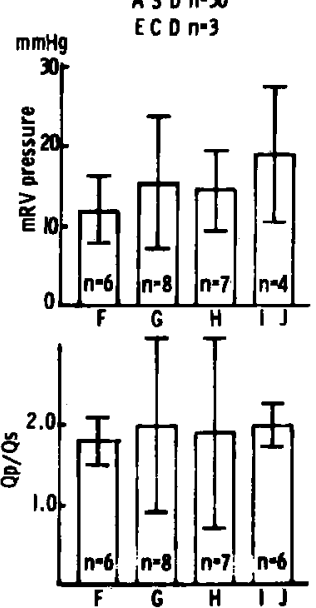

の方がよりく電位図で の重症度の指標の 1 つと 考えられるBreakthrough minimum の遅れと相関 を示した。次に Break through minimum の出 現部位と、これらの諸指 標との関係につき検討し た。(図13) 有意ではない が,RVDd, RVDd/LVDd が大きく，すなわち右室 搪張期径が大きくなるに つれ，また mRV pressure, mPA pressure が大 きくなるにつれて,Breakthrough minimum の出 現部位は $\mathrm{G} \rightarrow \mathrm{H} \rightarrow \mathrm{I} \sim \mathrm{J}$ とより左方に偏って出現

图13 A S D， E C D 症例の電位図におけるBreakthrough minuimumの出現部位と, 体表面積で補正した右室拡張期径 (RVDd)，右室拡張期径/右室拡張期径 - (RVDd / LVDd), 平均 右室圧 (mRV pressure), 平均肺動脈圧 (mPA pressure), 左右 短絡率 [S.R. $(\ell \rightarrow \mathrm{r})]$, 肺体血流比 $(\mathrm{Qp} / \mathrm{Qs})$ との比較

Map. pattern
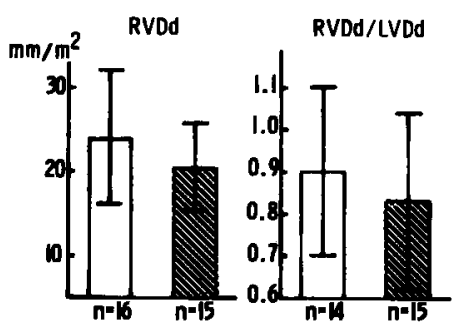

S. R. $(1+r)$
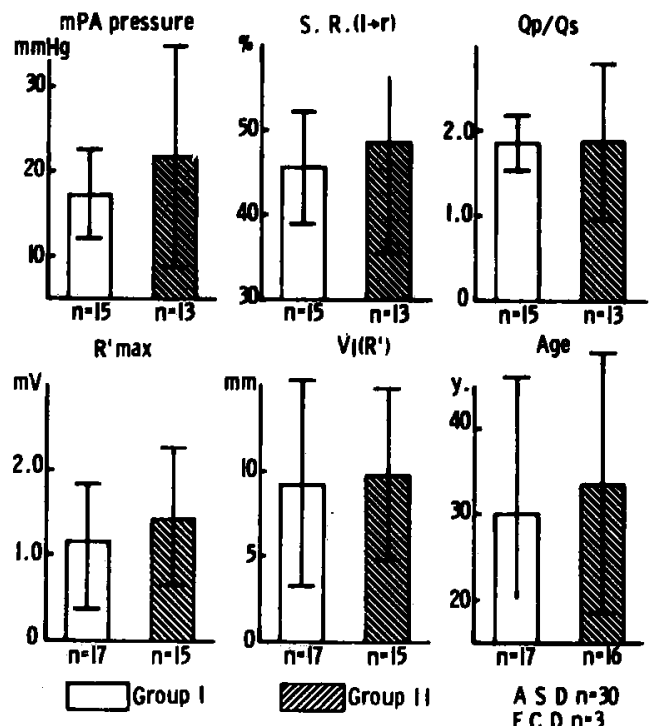

図14 電位図の型別 (Group I，Group II) での体 表面䅡で補正した右室应張期径 (RVDd)，右 室拡張期径 / 左室拡張期径 (RVDd/LVDd), 平均右室圧 (mRV pressure), 平均肺動脈圧 (mPA pressure), 左右短絡率 [S.R. $(\ell \rightarrow \mathrm{r})]$, 肺 体血流比 (Qp / Qa), QRS 後期における右㑡前 胸部における最大陽性電位 $\left(\mathrm{R}^{\prime} \max \right)$ ，心電图 $\mathrm{V}_{1}$ 誘導における $\mathrm{R}^{\prime}$ の電位 $\left[\mathrm{V}_{1}\left(\mathrm{R}^{\prime}\right)\right]$, 年路との 比較 


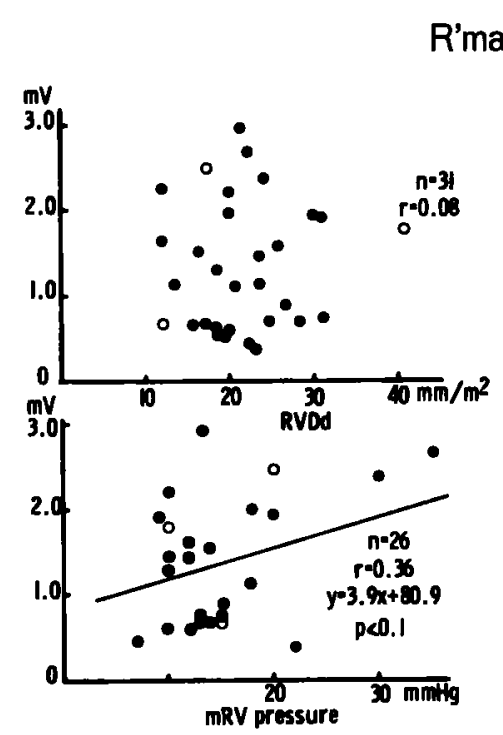

R'max. voltage $\begin{gathered}\text {-ASD } \\ \text { OECD }\end{gathered}$
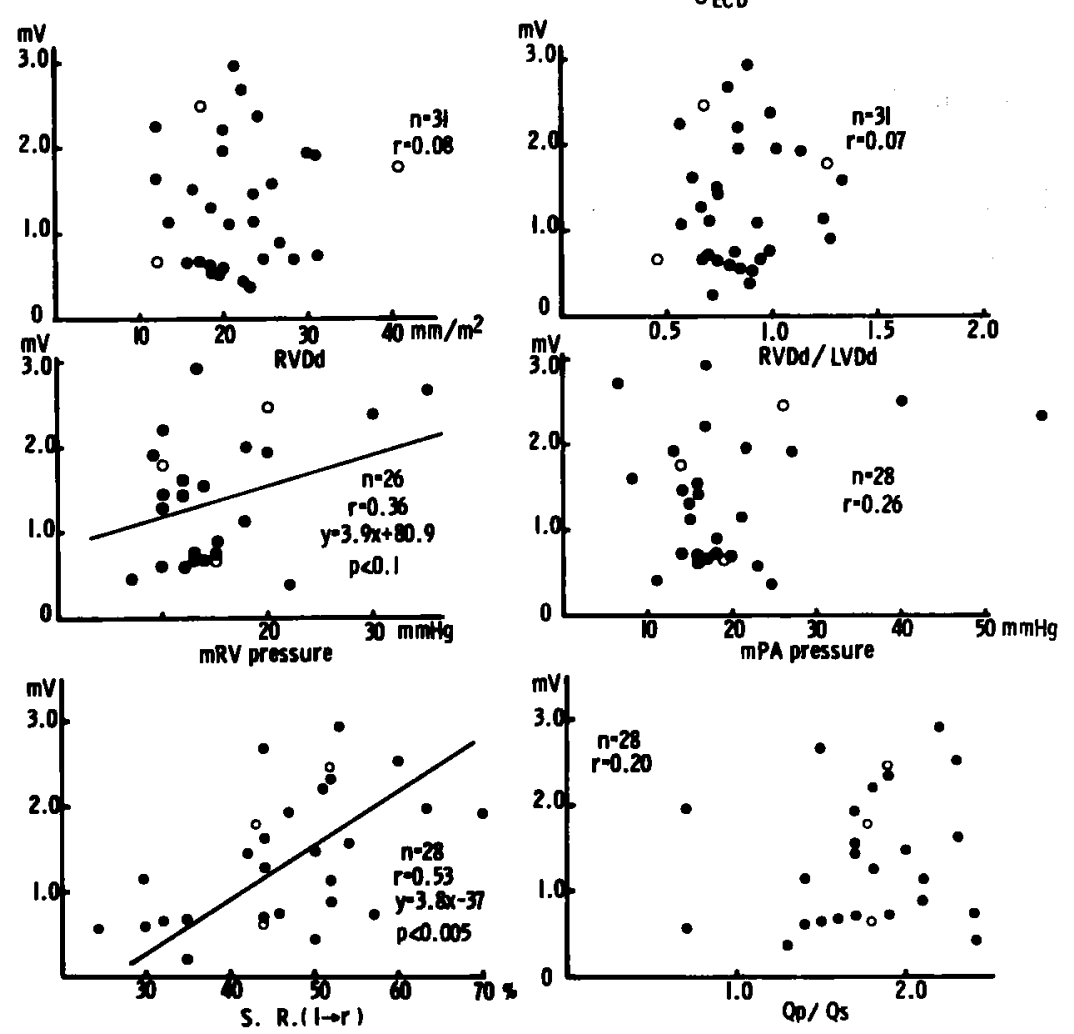

図15QRS 後期における右側前胸部における最大陽性電位（R' max voltage) と, 体表面積で補正した右室拡張期径 (RVDd), 右室拡張 期径/左室拡張期径 (RVDd/LVDd), 平均右室压 (mRV pressure) 平均肺動脈圧 (mPA pressure), 左右短絡率 [S.R. $(\ell \rightarrow \mathrm{r})$ ], 肺体血流 比 $(\mathrm{Qp} / \mathrm{Qs})$ との比較

する傾向が認められた. S.R.やQp/Qs の指標 は, Breakthrough minimumの出現部位とは良 い関係はなかった。次に, 右室の伝導遅延によ $\eta ， \mathrm{QRS}$ 後期に $\mathrm{A} \sim \mathrm{F}$ の右側前胸部に存在する 正領域における最も高い電位を $\mathrm{R}^{\prime}$ max voltage として求め,これと他の諸指標との関係につい て検討を試みた。（図14）RVDd，RVDd/LV $\mathrm{Dd}, \mathrm{mPA}$ pressure, Qp/Qsなどとの相関は得ら れなかったが, $\mathrm{mRV}$ pressure とは, $\mathrm{R}^{\prime} \max$ voltage が大になるにつれ，平均右室圧も大きくなる 傾向が認められ，とくにS.R. (左右短絡率) と は0.5\%以下の危険率で, R' max voltage が大 きくなるにつれ，有意に左右短絡率も大きくな る結果が得られた。すなわち, 左房から右房, 右室への短絡量が多くなり, 右室の流量負荷が
多くなるほど，右前胸部での陽性電位は高くな ると考之られた。一般に, 標準12誘導心電図で の, 胸部誘導 $\mathrm{V}_{1}$ の late $\mathrm{R}\left(\mathrm{R}^{\prime}\right)$ は, 右室流出路 附近, 室上槙 (crista supraventricularis)の肥 厚に起因するといわれており23224), Raunio ら ${ }^{25)}$ も $\mathrm{V}_{1}$ 誘導で rsr'を呈する1078名での剖検心との 対比で，30歳以上の例では病的意味を有するこ とが多く, $\mathrm{rsr}^{\prime}\left(\mathrm{r}^{\prime}>\mathrm{r}\right)$ ，または $\mathrm{Qr}$ パ夕ーンを 示すものでは，特に $57 \%$ ３0\%に右室肥大を伴 つているものがあると報告している。著者らの 電位図からの $\mathrm{R}^{\prime}$ max voltageの指標は, $\mathrm{V}_{1}$ 誘 導の $R^{\prime}$ voltage だけとの相関より明らかに良好 であり，右室の負荷動態を知るより良い指標に なり得ると考えられた，次に，ASD,ECD 例の 電位図での型別（Group I，Group II）での， 
他の諸指標との関係を検討した。（図15）Group I, 寸なわち右室拡大により右室流出路附近で の興奮伝導が遅延すると考えられている方が, Group IIに比し右室径の拡張の程度（RVDd， RVDd/LVDd) は大きい傾向が認められた。他 $の \mathrm{mRV}$ pressure, mPA pressure, $\mathrm{R}^{\prime}$ max voltage, $V_{1} の R^{\prime} の$ voltage などの指標について は, Group II，すなわち右室流量角荷に伴う 右室基部の選択的な肥大により，右室流入路の 伝導遅延を生ずると考えられる方でより大きい 倾向が認められた。また，年跉もGroup II の 方がより高路である傾向がみられ、これらの結 果から推測するに, Group I は病態的には軽 く、病期も比較的早い時期で，右室の拡張期の 流量負荷を主とした病像であり，それが年を経 て，右室容量負荷の状態が長く続くと，ついに は右室基部流入路附近の右室の肥大をも合併し てくるため, Group II のような電位図パターン をとってくる可能性も考えられる。ちなみに Group II のようなパターンは, Fallot 四徵症 で著明な右室の肥大を伴う例でよくみられる型 である゙1ことからも、Group IIの方がASD, ECD の病態的には重篤である可能性も充分考え られる。最後にASD 30例に扔いて加秢ととも に電位図の Breakthrough minimum の出現時 間、出現部位がどう変わるかを検討してみた。

（図16）相関はあまり良くないが，加䀫ととも にBreakthrough minimum の出現時間は遅れ， より左方に偏って出現する傾向はうかがえる。 す゚なわち，一般的にASDの病態も加秢ととも に重くなり，右心系への負荷の程度も増大し， そのために右室の伝遒遅延の程度も大となり，

Breakthrough minimum の出現時間もより䐅 れ, 左方に偏位して出現する可能性も考えられ る. 正常電位図での Breakthrough の出現が, 加秢とともにどうなるかという報告は無く，果 してこれが単なる加踴のみの影響か，ASD の 心血行動態を介する経年的な影響に因るのか確 証はないが、恐らくは後者によるものと考えら れる.今回は, ASD. ECD とも比較的軽症から 中等症程度の症例ばかりであり, 電位図からの 右心負荷の指標としての Breakthrough minimum や， $R^{\prime}$ max voltage，電位図の型別(Group
Age ASD $n=30$
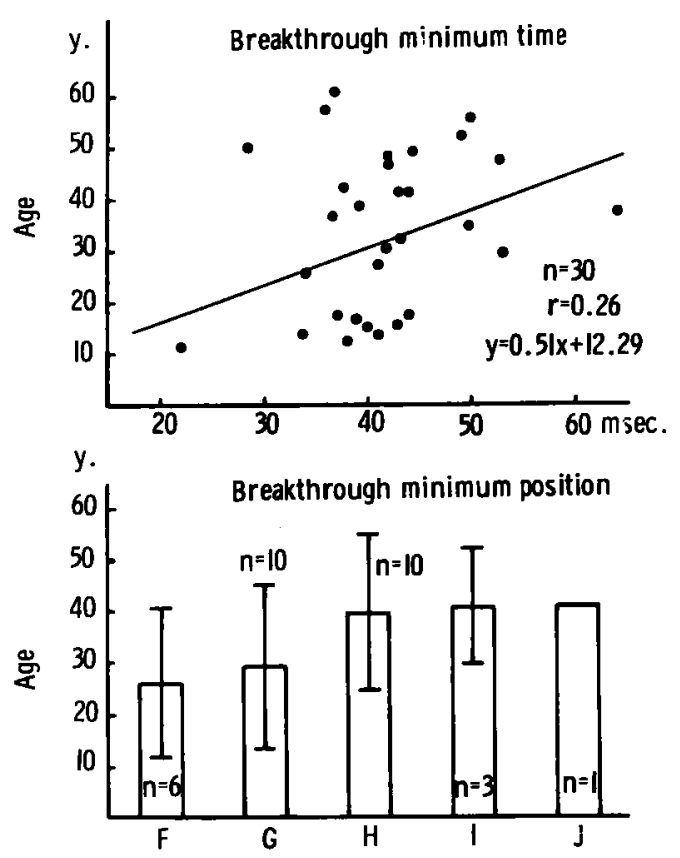

図16. ASD 症例の電位图における Breakthrough minimumの出現時間, 出現部位と加齢との関係

I, Group II ) と, 右心カテーテルからの $\mathrm{mRV}$ pressure, mPA pressure, S.R., Qp/QsやU.C.G. からのRVDd, RVDd/LVDdなどの右心負荷の 諸指標との对比は，必ずしも良い相関は得られ なかったが, しかし今後, 重症例, 軽症例とも に症例数を增すことにより，もっと良い相関も 得られると考えられる. 少なくとも，臨床心電 図法の $1 つ の$ 新しい手段として，非観血的に， $\mathrm{ASD}, \mathrm{ECD}$ 例などの病態, 重症度などを知るこ とが，電位図を記録することにより可能となる ことは充分考えられる.今後は，さらに手術前 後での電位図と心血行動態的諸指標との検討や, 病理組織学的な検討と对比させていくことによ $\eta$, 電位図の, 心疾患, 特に右心系疾患への臨 床応用が有意義なものになっていくものと考之 られる.

\section{まと め}

心電四上，右脚ブロックを呈するASD 30例 ECD 3 例, さらに心血管系に異常を認めない 5 例につき体表面心臟電位図を記録し，心臓力テ 
一テル検查, 心䁍超音波検查から得た諸指標と 对比検討した。

1) 右脚ブロック例では, 健常者例に比し電 位図での Breakthrough minimum の出現時間 は有意に遅延し，その出現部位は左方に偏位し た。

2 ) ASD, ECD例では, 心臓カテーテル検查 での, 肺体血流比, 左右短絡率, 心胹超音波検 査での右室应張期径が大きくなるにつれ，電位 図でのBreakthrough minimum の出現時間は 遅延し, 平均右室圧, 平均肺動脈圧, 右室应張 期径が大になるにつれBreakthrough minimum の出現部位は左方に偏って出現した。

3) QRS 後期の右側前胸部での最大陽性電 位 $R^{\prime}$ max voltage は平均右室压, 左右短絡率
が大きくなるにつれ，大になった。

4) ASD例では, 加粭とともに, Breakthrough minimum の出現時間は遅延し, 出現部位 は左方に偏位した。

以上の如く，ASD，ECD 例での電位図では， Breakthrough minimum の出現が遅れ, 左方 に偏って出現した。これは右室の拡張による右 室の伝導遲延や，右室肥大の合併などが原因し ていると考之られ，心䁍カテーテル検查，心睵 超音波検查などからの諸指標と对比し, ある程 度, 病態の重症度との関係が認められた。

（最後に，御校閲を賜った長島秀夫教授に深謝いた します.)

\section{文献}

1. Penalozad, D., Gamboa, R. and Sime, F.: Experimental right bundle branch block in the normal human heart. Am. J. Cardiol. 8, 767-779, 1961.

2. Toyama, S., Suzuki, K., Ishiyama, T., Yamaguchi, T., Terada, A., Tsukamoto, N. and Morita, K.: Vectorcardiogram in Right Bundle Branch Block with Frank System. Jpn. Circ. J. 28, 230-234, 1964.

3. Tokunaga, T.: Electrocardiogram and vectorcardiogram in isolated complete right bundle branch block. Part I clinical studies. Jpn. Circ. J. 37, 941-956, 1973.

4. 菅屋潤壹, 大野三良, 河辺達夫, 太田寿城, 服部良信：右脚ブロックの体表面心臓電位図。循環器科。5， 280-290, 1979.

5. 山田和生, 岡島光治, 立松 廣, 任書 煌, 伊藤厚士, 豊嶋英明, 大熊 攻, 和田正敏 : 体表面心荗電位 分布図の研究．正常例について。琵研年報．24，101-108，1973.

6. 山田和生：体表面電位图とは。循環器科。 $5,247-253,1979$.

7. Taccardi, B., Ambroggi, L. de. and Riva, D.: Chest maps of heart potentials in right bundle branch block. J. Electrocardiol. 2 , 109-116, 1969.

8. Sugenoya, J.: Interpretation of the body surface isopotential maps of patients with right bundle branch block. Determination of the region of the delayed activation within the right ventricle. Jpn. Heart J. 19, 12-27, 1978.

9. Sugenoya, J., Sugiyama, S., Wada, M., Niimi, N., Oguri, H., Toyama, J. and Yamada, K.: Body surface potential distribution following the production of the right bundle branch block in dogs. Effects of breakthrough and of right ventricular excitation on the body surface potentials. Circulation, 55, 49-54, 1977.

10. 山田和生, 外山淳治, 豊嶋英明, 小栗 孟, 大野三良, 太田寿城, 福慶逸郎, 服部良信, 河辺達夫：体表 面心荿電位分布図による不完全プロックの研究一心房中隔欠損症の症例について一 環研年報，29，9295, 1978.

11. Blumenschein, S.D., Spach, M.S., Boineau, J.P., Barr, R.C., Galliie, T.M., Wallace, A.G. and Ebert, 
P.A.: Genesis of body surface potentials in varying type of right ventricular hypertrophy. Circulation. 38, 917-932, 1968.

12. 山田和生, 外山淳治, 永田昌久, 伊藤厚士, 豊嶋英明, 小栗 孟, 清水 武, 小池斌碩, 大熊 攻, 新美 伸朗, 菅屋潤喜, 杉山 理, 和田正敏：体表面心荿電位分布図の研究（II）一心房中隔欠椇症について一 環研年報. 25，89-93，1974.

13. Durrer, D., Roos, J.P. and van Dum, R. Th.: The genesis of the electrocardiogram of patients with ostium primum defects (ventral atrial septal defects). Am Heart J. 71, 642-650, 1966.

14. Boineau, J.P., Spach, M.S. and Ayers, C.R.: Genesis of the electrocardiogram in atrial septal defect. Am. Heart J, 68, 637-651, 1964.

15. Karsh, R.B., Spach, M.S. and Barr, R.C.: Interpretation of Isopotential Surface Maps in Patients. with Ostium Primum and Scundum Atrial Defects. Circulation, 41, 912-933, 1970.

16. Lev, M.: Conduction System in Congenital Heart Disease. Am. J. Cardiol. 21, 619-627, 1968.

17. Boineau, J.P., Moore, E.N. and Patterson, D.F.: Relationship between the ECG, Ventricular activation and the ventricular conduction system in ostium primum ASD. Circulation 48, 556-564, 1973.

18. Moore, E.M., Hoffman, B.F., Patterson, M.D. and Stuckey, J.H.: Electrocardiographic changes due to delayed activation of the wall of the right ventricle. Am. Heart J. 68, 347-361, 1964.

19. 山田和生, 外山淳治, 小栗 孟, 菅屋润壹, 和田正敏, 杉山 理, 池田信男, 大野三良：体表面心葴電位 分布図による実験的不完全右脚ブロックの研究一右脚側枝切断による検討一 環研年報. 28, 83-86, 1977.

20. Walker, W.J., Mattingly. T.W., Pollock, B.E., Carmicael, D.B., Inmon, T.W. and Forrester, R.H.: Electrocardiographic and hemodynamic correlation in atrial septal defect. Am. Heart J. 52, 547-561, 1956.

21. Farch, G.: An analysis of the excitation wave in the human ventricle. Arch. Int. Med. . Med. 25, 146 $-173,1920$.

22. 山田和生, 外山淳治, 小栗 孟, 新美伸朗, 菅屋潤壹, 杉山 理, 和田正敏, 体表面心臟電位分布四, 日 本人健康成人について。環研年報，27，103-108，1976.

23. Pyor, R., Woodwark, G.M. and Blount, G.: Electrocardiographic changes in Atrial Septal Defects: Ostium Secundum Defect Versus Ostium Primum (Endocardial Cushion) Defect. Am. Heart J. 58, 689-700, 1959.

24. Burch, G.E. and Depasquale, N.P.: Electrocardiogram and Spatial Vectorcardiogram of Locarized Myocardial Hypertrophy. Circulation 26, 544-552, 1962.

25. Raunio, H., Rissanen, V., Jokinen, C. and Pentilă, O.: Significance of a terminal R wave in Lead $\mathrm{V}_{1}$ of the electrocardiogram. Am. Heart J. 95, 702-706, 1978. 
Body surface isopotential maps in the case of R.B.B.B. special reference to Atrial Septal Defect.

(Comparative study of the data from cardiac catetherization and two dimensional echocardiograms.)

Hidenori YOSHIDA, Kazuo IHORIYA, Haruki NAGAHANA, Masanobu NISHIHARA, Tatsuo HYODO, Toshiaki UCHIDA, Masashi KIMURA, Kou TAKEDA, Akinobu FuJIl and Daiji SAITo The First Department of Internal Medicine, Okayama University Medical School, Okayama

(Director: Prof. H. Nagashima)

Setsuro TANATANI, Toshimasa KITA and Hiroshi SAKAI

Sakakibara Juzen Hospital

Shoichi HARAOKA

Physiological Section, Central Laboratory, Okayama University

Medical School

A body surface isopotential map was recorded in 30 cases of ASD and 3 cases of ECD with right bundle branch block in ECG, then analyzed in comparison with results obtained by cardiac catetherization and two dimensional echocardiograms.

1) In all cases of right bundle branch block, breakthrough minimum appeared later and shif ted to the left compared with the normal.

2) Breakthrough minimum of ASD and ECD appeared progressively later associated with Qp/Qs ratio and left to right intracardiac shunt ratio obtained with cardiac catetherization and RVDd with echocardiogram. Breakthrough minimum of ASD and ECD -moved to the left accompanied by increases in mean RV pressure, mean PA pressure and RVDd.

3) $R^{\prime} \max$ voltage, the maximum positive potential in the late stage of ventricular depolarization on the right precordial area, increased and correlated well with the mean RV pressure and left to right shunt ratio increment.

4) In the case of ASD, breakthrough minimum appeared later and shifted to the left along with age. 